\section{References}

1. Khromov-Borisov N. V., Karlinskaya R. S. Sintezy i prevrashheniya proizvodnykh pirimidina. Sul'foproizvodnye tsitozina, 4-metiltsitozina i uratsila // Zhurnal obshhey khimii. 1957. Vol. 27, No. 9. P. 2518-2521.

2. Khromov-Borisov N. V., Karlinskaya R. S. Sintezy i prevrashheniya proizvodnykh pirimidina. Sul'firovanie proizvodnykh pirimidina // Zhurnal obshhey khimii. 1954. Vol. 24, No. 8. P. $2212-2215$.

3. Pokhidni 6-metil-2,4-digidroksipirimidin-5-sul'fonamidu i sposib ikh oderzhannya: pat. 75516 UA. MPK A61P 31/12, C07D 239/69, A61P 31/04, A61K 31/505 / Pogorelova I. P., Isak A. D. Appl. No. 20040806492; Filed: 03.08.2004; Published: 17.04.2006. Bull. No. 4.

4. Pogorelova I. P., Orlov V. D., Isak A. D. Synthesis of 6-methyluracil5-sulfonyl chloride // Russian Journal of Applied Chemistry. 2006. Vol. 79, No. 4. P. 631-633. doi:10.1134/s1070427206040240

5. Elderfield R. C., Prasad R. N. Synthesis of Potential Anticancer Agents. XI. Synthesis and Reactions of Derivatives of 6-Methyluracil-5-sulfonic Acid1, $2 / /$ The Journal of Organic Chemistry. 1961. Vol. 26, No. 10. P. 3863-3867. doi:10.1021/ jo01068a058

6. Sposib otrymannia 6-metyluratsyl-5-sulfokhlorydu: pat. 106558 UA. MPK A01N 25/00, C07C 307/00, A61K 31/08 / Abdo-Allah M., Shypydchenko M. V., Isak A. D. Appl. No. u 201511581; Filed: 23.11.2015; Published: 25.04.2016. Bull. No. 8.

7. Melnikov N. N. Pestitsidy. Khimiya, tekhnologiya i primenenie. Moscow: Khimiya, 1987. 712 p.

8. Halo-Substituted Cyanomethyl Benzenesulfonates: pat. US3873591A / Smith H. Q., Toukan S. S.; assignee: Pennwalt Corp. Published: 25.03.1975.

9. Fungicidal Compositions and processes using azonaphthol sulphonic acid derivatives: pat. GB1427516A; assignee: Imperial Chemical Industries Ltd. Published: 10.03.1976.

10. Double salt of copper alkyl phenolsulphonate an d basic calcium useful as agricultural germicide: pat. DE2533102A1; assignee: Yonezawa Chemical Industries Co Ltd. Published: 27.01.1977.

11. Perfluoroalkanesulfonate ester Herbicides: pat. US3954828A Fridinger T. L. Published: 04.05.1976.

12. Wegler H. K. Chemie der Pflanzenschuetz und Schudlingsbekampfungsmittell. Vol. 8. Berlin: Springer. Verlag, 1982. 485 p.

13. Jenkins F., Hambly A. Solvolysis of Sulphonyl Halides. I. The Hydrolysis of Aromatic Sulphonyl Chlorides in Aqueous Dioxan and Aqueous Acetone // Australian Journal of Chemistry. 1961. Vol. 14, No. 2. P. 190-212. doi:10.1071/ch9610190

14. Linetskaya Z. G., Sapozhnikova N. V. Kinetika gidroliza nekotorykh sul'fokhloridov aromaticheskogo i zhirnogo ryada // Doklady AN SSSR. 1952. Vol. 6, No. 4. P. 763-766.
15. Tommila E., Jutila J., Burstrom H. Hydrolysis and Alcoholysis of Sulphonic Esters // Acta Chemica Scandinavica. 1952. Vol. 6. P. 844-853. doi:10.3891/acta.chem.scand.06-0844

16. Reutov O. A. Teoreticheskie osnovy organicheskoy khimii. Moscow: MGU, 1964. 700 p.

17. Ingold K. Teoreticheskie osnovy organicheskoy khimii. Moscow: Mir, 1973. 1056 p.

18. Dneprovskiy A. S., Temnikova T. I. Teoreticheskie osnovy organicheskoy khimii. Leningrad: Khimiya, 1991. 560 p.

\section{ПОИСК НОВЫХ БИОЛОГИЧЕСКИ АКТИВНЫХ СОЕДИНЕНИЙ} НА ОСНОВЕ 6-МЕТИЛУРАЦИЛ-Б-СУЛЬФОХЛОРДА И СПИРТОВ

Проведено исследование реакции взаимодействия алифатических и ароматических спиртов с 6-метилурацил-5-сульфохлоридом (МУСХ). Показано, что удобней всего проводить взаимодействие 6-метилурацил-5-сульфохлорида с предварительно приготовленным алкоголятом в избытке исходного спирта. Предварительные исследования (использование программы PAAS) показали, что среди полученных соединений имеются такие, которые проявляют антиоксидантные свойства и могут быть использованы в качестве цитостатиков.

Ключевые слова: биологически активные соединения, синтез алкилсульфонатов на основе 6-метилурацил-5-сульфохлорида и алкоголятов, реакционная способность.

Abdo-Allah Masud, Postgraduate Student, Department of Ecology, Institute of Chemical Technologies of the Volodymyr Dahl East Ukrainian National University, Rubizhne, Lugansk region, Ukraine, ORCID: https://orcid.org/0000-0002-8403-5301

Mospanova Elena, PhD, Associate Professor, Shupyk National Medical Academy of Postgraduate Education, Kyiv, Ukraine, e-mail: elena_mospanova@list.ru, ORCID: https://orcid.org/0000-0002$6575-5135$

Popov Yevgeniy, Doctor of Technical Sciences, Professor, Department of Ecology, Institute of Chemical Technologies of the Volodymyr Dahl East Ukrainian National University, Rubizhne, Lugansk region, Ukraine, e-mail: popov@iht.lg.ua, ORCID: http://orcid.org/00000001-7941-5134

Isak Alexandr, PhD, Associate Professor, Department of General Chemistry Disciplines, Institute of Chemical Technologies of the Volodymyr Dahl East Ukrainian National University, Rubizhne, Lugansk region, Ukraine, e-mail: isak_ad@ukr.net, ORCID: https:// orcid.org/0000-0002-9985-5011

\section{Artemev 5., Shaporev V., Tsymbal B.}

\title{
INVESTIGATION OF METHODS OF OBTAINING WHISKERS IN COMPOSITE MATERIAL
}

Досліджено методи отримання ниткоподібних кристалів у композиційному матеріалі. Зосереджено увагу на процесі отримання ниткоподібних кристалів хімічною взаємодією між газом та контактною речовиною, а також методом (пар - рідина - тверде). Показано перевагу проведення процесу конденсації крізь рідку фазу у порівнянні з прочесом прямої конденсації з парової фази у тверду.

Ключові слова: методи отримання ниткоподібних кристалів, композиційні матеріали, хімічна взаємодія між газом та контактною речовиною.

\section{Introduction}

The methods of obtaining whiskers for a long time continue to be a rather urgent problem for the study of modern science. This is evidenced by an increase in the problems of these issues during scientific conferences and seminars, since any obtained experimental result deserves discussion and consideration. Scientists should clearly welcome 
the fact that it is appropriate and necessary to cover the results and make critical remarks and constructive proposals.

The methods of obtaining whiskers are precisely related to the issues of wide discussion and construct. After all, it is this area of knowledge that is becoming increasingly important in modern conditions. And the range of its practical application is constantly expanding, affecting already electronics, solid state physics and other areas.

The methods of obtaining whiskers and their growing in the 20th century depended very often solely on the skill of the scientist conducting this or that experiment. However, over the last 30 years, the industry has taken steps forward, which has made the spectrum of obtaining this group of crystals very different.

These successes have been and are taking place thanks to an understanding of those phenomena that can take place in crystallization apparatuses and even more so on the surface of a growing crystal. Despite the complexity of the ongoing processes and the existing large body of physical and chemical phenomena, research in this area is successfully continuing and does not lose relevance.

\section{The object of research and its technological audit}

The object of this research is the methods of obtaining whiskers in composite materials.

In particular, the method of obtaining whiskers by reduction of metal halides by the example of the basic scheme of this process is considered and studied. The essence of this method and the processes of chemical gasphase interaction that occur inside the quartz tube are investigated.

According to another schematic diagram, the growth of whiskers of $\mathrm{SiC}$ by the «vapor-liquid-solid» (VLS) method is studied. The essence of this process is the ongoing reactions and conclusions on the processes performed by each of the studied methods.

A problematic issue of the application of both methods is the temperature interval for carrying out the processes, which can be associated with the process of recrystallization of a particular whisker. And in this case, one should take into account the fact that each crystal has its own. And the temperature range is quite wide - from room temperature and to the firing temperature. Therefore, it is difficult to determine which of the recrystallization processes is more successful when using each of the methods and using a particular crystal.

\section{The aim and objectives of research}

The aim of research is reviewing the existing ideas about some methods of obtaining whiskers in a composite material.

To achieve this aim, it is necessary to solve such problems:

1. To investigate the method of obtaining whiskers in the process of chemical interaction between a gas and a whisker, followed by transfer of the reaction product to the deposition zone and its crystallization.

2. To investigate the method of obtaining VLS whiskers during the condensation of whiskers from the vapor phase to the solid phase through the intermediate-liquid phase.

\section{Research of existing solutions of the problem}

Among the sources of literature that address issues related to the growth and growth of whiskers, the following can be attributed.

For example, in [1] the author studies in detail the growth of filamentous and lamellar crystals from vapor, and the emphasis of investigations on the obtaining of whiskers from the gas phase is indicated in [2].

The source [3] considers the gas-phase metallization of metallic crystals in carbonyls, and in [4] the problems of deposition of metal films and coatings through the process of decomposition of organometallic compounds are discussed.

Nor were the problems of growing whiskers grown in the gas phase during the chemical interaction, as described in [5], including in the melt medium [6].

It was in the second half of the 20th century that the perspectives of this issue were widely reflected during conferences and scientific seminars, the development of advanced technological processes using whiskers [7-11].

It should also be noted that the issue of obtaining (growing) such crystals in an electric field, for example, using additional electric heating in crystallization chambers [12], is considered as a separate aspect. The problems of obtaining films of whiskers are discussed in [13, 14], which was also reflected in $[7,8]$.

In [10], the results of the use of grown (obtained) groups of whiskers in various industries are published. Of course, it should be noted that such topics are partly considered in the dissertational studies of recent years, for example, in [15].

Within the framework of the literature review, these questions are systematized in [16-18].

The development of industry, science and technology confirms the fact that the circle of metals that can be obtained in a single-crystal form becomes wider. But the growing of such group of crystals is actually called «art», because the crystal itself is a kind of perfection. Moreover, the grown crystal, which is obtained with the given properties, does not at all mean that it is suitable for carrying out the tasks for which it is created. This is technology and new technological processes.

«If it is necessary to measure a property, then $80 \%$ of the effort and ingenuity is spent either on obtaining a metal or alloy in a very pure form and growing a single crystal of appropriate purity ... and only $20 \%$ of all effort is spent on the measurement of the property itself» [19].

The literature review shows that the most widely used method for obtaining crystals of both low-melting and refractory is the method of growing crystals from a melt in various interpretations. The advantage of this method is that it makes it possible to control the solidification of the crystal almost completely and, thus, to obtain crystals of the necessary orientation, as described in [20,21]

Container methods for growing crystals have been discussed in detail in [22-25]. These methods of preparation allow the raw material to be heated to a temperature that would be higher than its melting point, and then leave the crystal to cool, which allowed the formation of a solid phase in a certain place. In the same sources it is pointed out that the growth conditions of crystals can be higher when using magnetic fields designed to reduce the effects of convection. 
The method of obtaining whiskers, called the Czochralski method or «stretching», is described in [26-29].

The processes of growing crystals from molten metals are reflected in [30], and as a result of electric transport in the solid phase in $[31,32]$. The research results on these issues form the basis for the method of preparing small amounts of crystals from refractory materials, which is reflected in [33, 34]. The conservation of the high-temperature phase to room temperature is considered in [35], where it is shown by experiments that the obtained crystal modification may not be stable at low temperatures, and the electrodeposition method used for this is not effective. The problems of obtaining whiskers using electron-beam heating are described in [36], where it is shown that the probability of obtaining a single crystal with this method is significantly increased, which directly depends on the purity of the material.

Methods for obtaining crystals of refractory metals are considered in various versions:

- in [37] - with the introduction of arc furnaces;

- in [38] - with the introduction of the transfer method

in the arc;

- in [39] - with the help of lasers;

- in [40] - with the introduction of crucible-free melting zone with induction heating. True, in the latter case, the experiments did not take place with metals, but with solid alloys.

It should be noted that at the end of the last century the method of obtaining nanocrystals was very popular, which is described in [41-46]. These sources of literature describe the technology of evaporation and condensation methods for the production of such nanocrystals with a rotating cylinder, in a rarefied inert gas atmosphere, usually helium and a number of other directions.

Issues related to the microstructure of nanocrystalline materials have also been considered in many sources, for example, in $[47,48]$. It is here that the fact that a typical nanocrystal, as a rule, contains two components, crystallites and intercrystalline boundaries, is experimentally confirmed. True, such nanocrystal must consist of atoms of one kind.

Thus, the results of the literature analysis allow to conclude that the methods of growing various groups of whiskers have been studied extensively. Although it should be noted that more detailed study of this process was in the second half of the 20th century.

The prospectivity of the research problem shows that there are still a lot of «spots» and unresolved issues in this area of research. And the final choice of technically optimal solutions for the methods of growing each group of whiskers is yet to come.

\section{Methods of research}

The following methods are used during the research: - statistical analysis (to determine the existing changes in the improvement of methods for obtaining whiskers for a certain period);

- analysis of research results (to determine the positive and negative aspects of the application of a method of obtaining whiskers);

- hypothetic and deductive method (when acquainting the actual research material in the field of threadlike crystals, which additionally requires the analysis of a specific source of information);
- a method of generalizing the results (to establish the general properties and trends characteristic of different methods of obtaining whiskers).

\section{Research results}

6.1. Method for the reduction of halide metal salts. When this method is used, the whiskers are grown through the chemical reaction of the interaction between the substance that evaporates and the gas that is introduced. Later, the reaction products due to mass transfer go to the so-called deposition zone where the material crystallizes, as described in [49].

Fig. 1 is a schematic diagram of the process for obtaining a whisker as a result of such reaction between halogenated salt pairs that are formed as a result of heating and a reducing gas that is supplied to the reaction zone.

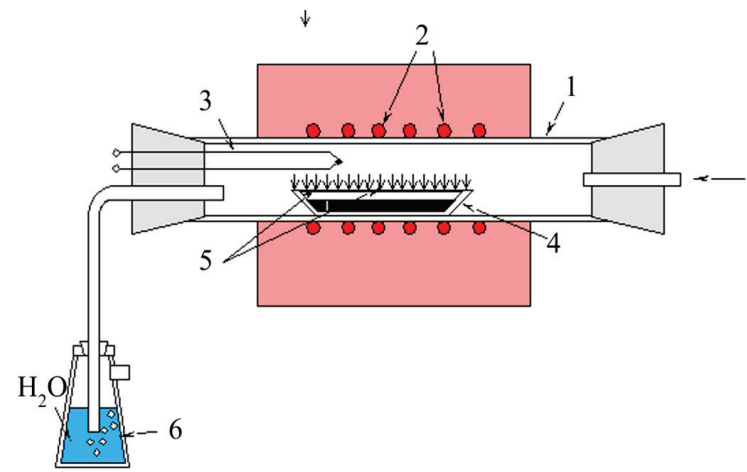

Fig. 1. Scheme of the process of obtaining metallic whiskers by the method of reduction of metal halides: 1 - quartz tube; 2 - heater; 3 - thermocouple; 4 - «boat» with a halide salt; 5 - metallic whisker; 6 - gas collection container

When using the first considered method, it should be noted that an electric current is passed through the heater (2), which provides heating and a set temperature. In turn, the temperature is maintained and controlled by a thermocouple (3). The volume of the quartz tube will be filled with a halide salt, which at the specified maintained temperature will provide the necessary concentration of the evaporated substance.

The simplest gas-reducing agent is hydrogen, which, in turn, is further diluted with an inert gas. When using, for example, the salt of $\mathrm{FeCl}_{2}$, the following chemical reaction will occur inside the quartz tube, as indicated in [50]:

$\mathrm{FeCl}_{2}$ (vapor) $+2 \mathrm{H}_{2} \rightarrow \mathrm{Fe}(\mathrm{w})+2 \mathrm{HCl} \uparrow$.

Supporting all process parameters, whiskers, for example, iron, will grow directly on the wall in the form of outgrowths having a fluffy shape.

6.2. The VLS method (vapor-liquid-solid). When this method is used, the whiskers are condensed from the vapor, but in this case the liquid (intermediate) phase passes.

Fig. 2 also shows a schematic diagram of an apparatus for growing $\mathrm{SiC}$ whiskers. In this scheme, the removable cover (4) plays the role of the substrate on the watercooled container (3).

The container in this scheme is a reactor where a gasphase interaction occurs. The interaction temperature can reach up to $1500{ }^{\circ} \mathrm{C}$. Inside the container, pure $\mathrm{Si}$ is placed, 
or a charge (2), which, when heated, secures the release of vapors, in this case, silicon. In the boat (1) there is a metal-dropping agent (for example, $\mathrm{Fe}$ or $\mathrm{Ni}$ ), which is capable of decomposition with extraction of free metal vapor.

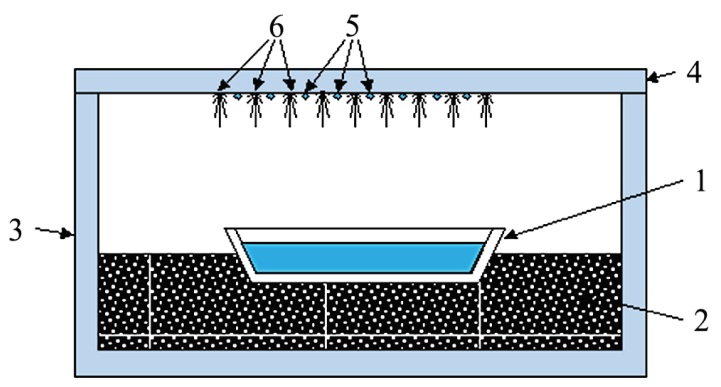

Fig. 2. Scheme of growing of $\mathrm{SiC}$ whiskers by the «vapor-liquid-solid» method: 1 - a boat with a metal-dropper; 2 - charge; 3 - container; 4 - removable cover; 5 - drops of metal; 6 - whisker

The space inside the container is filled with a gas mixture that must contain hydrocarbons. With the help of heating, the metal evaporates, which condenses on the lid in the form of droplets (5).

At the same time, the charge is evaporated, which is a source of silicon vapor. The vapors, in turn, interact with the hydrocarbons, and form a gaseous product of $\mathrm{SiC}$.

This interaction can be described by such reactions:

$\mathrm{Si}($ vapor $)+\mathrm{CO} \rightarrow \mathrm{SiC}($ gas $)+\mathrm{O}_{2}$

or

$\mathrm{Si}($ vapor $)+\mathrm{CH}_{4} \rightarrow \mathrm{SiC}($ gas $)+\mathrm{H}_{2}$.

Condensation of metal droplets should be during the whole process of growth of whiskers. This, in a sense, feeds the gas phase in the reactor with the corresponding pairs of the metal-dropper. It is then that metal droplets trap $\mathrm{SiC}$ atoms, dissolve them and release them into the solid phase.

When using the second method, shown in the schematic diagram (Fig. 2), metal droplets represent numerous centers of whisker crystallization, in this case silicon carbide (6). With this method, the crystallization of the compound in the liquid phase occurs at much lower degrees of supersaturation. And this determines the cost of time (they will be smaller).

\section{SWOT analysis of research results}

Strengths. Strengths are the following when using the VLS method («vapor-liquid-solid»):

1. Large area of crystallization due to evaporation of metal droplets. The number of crystallization centers is constantly increasing when the process parameters are observed.

2. In the liquid phase, crystallization has a lower degree of supersaturation, which in turn reduces the time required to produce a crystal and grow it.

3. Atoms of the precipitated substance have a higher accommodation coefficient for the atoms of this substance by the liquid, which in turn leads to an increase in the growth rate of the crystals.
Weaknesses. To the weak sides, which relate to various methods of growing crystals of refractory metals, one can include:

1. The problem of «cleanliness» and «perfection» of a metal, grown crystal does not mean that it meets the necessary requirements, but it's economic costs, the role of the human factor, the imperfection of equipment.

2. It is difficult to trace the redistribution of its components during crystal growth, this leads to difficulties in obtaining a crystal of the desired composition and often does not allow obtaining the desired phase at a given temperature.

3. Even having «perfection», «purity» and the necessary orientation, it may not be suitable, since it needs to be shaped by rather complicated profiling methods.

4. The complexity of modifying crystal growth techniques that could allow simultaneous production of crystals of the desired purity, shape, and orientation simultaneously.

5. Performing even existing (ideal) requirements for crystal growth, it is always necessary to have a starting material, for example, a single-crystal material for obtaining a single crystal, which is not always possible.

Opportunities. The conducted studies on the first of the methods for obtaining whiskers in a composite material show:

1. Using this process scheme and using halide salts of various metals, one can eventually obtain a sufficiently high vapor concentration of the evaporated substance.

2. It is economically advantageous to use hydrogen as a reducing gas in this method.

3. The process takes place fairly quickly and clearly (crystals grow directly «in front of»).

Threats. To the problem areas that prevent the introduction of this product, it is possible to include:

1. The impossibility of combining in one operation to grow crystals of various technological factors, which leads to the impossibility of significantly saving time and effort.

2. Expensive, perfect and unique equipment, which would allow the use of grown crystals without additional processing.

\section{Conclusions}

1. The method of obtaining whiskers in the course of chemical interaction between a gas and a whisker, followed by transfer of the reaction product to the deposition zone and its crystallization are investigated. It is shown that the use of such method makes it possible to obtain a high concentration of solute, which ultimately affects the crystal structure.

2. Investigation of the method of obtaining «vaporliquid-solid» whiskers during the condensation of whiskers from the vapor phase to the solid phase through the liquid phase is carried out. It is substantiated that with the application of such method, the number of crystallization centers increases significantly, which leads to an acceleration of the crystal growth process.

\section{References}

1. Givargizov E. I. Rost nitevidnykh i plastinchatykh kristallov iz para. Moscow: Nauka, 1977. 304 p.

2. Berezhkova G. V. Nitevidnye kristally. Moscow: Gosizdat, 1969. $158 \mathrm{p}$.

3. Syrkin V. G. Karbonily metallov. Moscow: Khimiya, 1983. 200 p 
4. Gribov B. G., Domrachev G. A., Zhuk B. V. Osazhdenie plenok i pokrytiy razlozheniem metalloorganicheskikh soedineniy: handbook. Moscow: Nauka, 1981. 322 p.

5. Gabor B., Blocher V. Blocher Neposredstvenno nabliudaemyi pod mikroskopom rost zheleznyh viskerov, himicheski vyrashchivaemyh iz gazovoi fazy // Journal of Applied Physics. 1969 Vol. 7. P. 224-226.

6. Ivanova V. S., Gordenko L. K. Novye puti povysheniya prochnosti metallov: handbook. Moscow: Nauka, 1964. 118 p.

7. Nitevidnye kristally i tonkie plenki: proceedings // Nitevidnye kristally. Voronezh: VPI, 1975. 466 p.

8. Nitevidnye kristally dlya novoy tekhniki: proceedings. Voronezh: VPI, 1979. $231 \mathrm{p}$

9. Ammer S. A., Postnikov V. S. Nitevidnye kristally: handbook. Voronezh: Politekh. Instit., 1974. 284 p.

10. Nitevidnye kristally / Shishelova T. I. et al. // Uspekhi sovremennogo estestvoznaniya. 2009. Vol. 8. P. 12-13.

11. Nitevidnye kristally: proceedings // Issledovaniya i razrabotki po prioritetnomu napravleniyu razvitiya nauki, tekhnologiy i tekhniki «Industriya nanosistem i materialy / ed. by Gudilin E. A. Moscow: FGU » Rossiyskiy nauchnyy tsentr «Kurchatovskiy institut». 2007

12. Givargizov E. I. Teoriya rosta i metody vyrashhivaniya kristallov. Moscow: Mir, 1981. 220 p.

13. Nitevidnye kristally i neferromagnitnye plenki: proceedings // Part 1. Nitevidnye kristally. Voronezh: VPI, 1970. 287 p.

14. Nitevidnye kristally i neferromagnitnye plenki: proceedings // Part 2. Tonkie plenki. Voronezh: VPI, 1970. 300 p.

15. Nomeri M. A. K. Poluchenie i issledovanie opticheskikh svoystv poluprovodnikovykh oksidov $\mathrm{ZnO}_{2}$ i $\mathrm{Zn}_{2} \mathrm{O}_{3}$ : PhD thesis. Voronezh, 2011. 128 p.

16. Artemev S. R. Present concepts of non-traditional methods of growing of metal whisker crystals. Pulling of whiskers from solution // Technology Audit and Production Reserves. 2015. Vol. 3, No. 4 (23). P. 8-12. doi:10.15587/2312-8372.2015.42409

17. Artemev S. R. Current concepts of non-traditional methods of cultivation metal whisker crystals. Pulling whisker pole from melt // Technology Audit and Production Reserves. 2015. Vol. 2, No. 4 (22). P. 16-19. doi:10.15587/2312-8372.2015.40499

18. Artemev S. R., Belan S. V. Properties and basic methods of receipt of threadlike crystals // Eastern-European Journal of Enterprise Technologies. 2013. Vol. 5, No. 1 (65). P. 22-26. URL: http://journals.uran.ua/eejet/article/view/18160

19. Les Elements Des Terres Rares. Vol. 1 / Spedding F. H. et al. Editions du Centre Nat. de la Recherche Scientifique, 1970. P. 25.

20. Chalmers B. Principles of Solidification. New York: Wiley, 1964. 319 p.

21. Liquid Metals and Solidification. Cleveland: American Society for Metals, 1958.

22. Gow K. V., Chalmers B. The preparation of high melting point metal single crystals and bicrystals with pre-determined crystallographic orientation // British Journal of Applied Physics. 1951. Vol. 2, No. 10. P. 300-303. doi:10.1088/0508-3443/2/10/305

23. Hurle D. T. J. Temperature oscillations in molten metals and their relationship to growth striae in melt-grown crystals // Philosophical Magazine. 1966. Vol. 13, No. 122. P. 305-310. doi:10.1080/14786436608212608

24. Utech H. P., Flemings M. C. Elimination of Solute Banding in Indium Antimonide Crystals by Growth in a Magnetic Field // Journal of Applied Physics. 1966. Vol. 37, No. 5. P. 2021-2024. doi:10.1063/1.1708664

25. Nacken R., Neues J. B. Uber das Wachstum von Kristallpolyedern in ihrem Schmelzfluß // Mineralog. Geol. Palaontol Ref. Teil. 1915. No. 2. P. 133-164

26. Kyropoulos S. Ein Verfahren zur Herstellung großer Kristalle // Zeitschrift Für Anorganische Und Allgemeine Chemie. 1926. Vol. 154, No. 1. P. 308-313. doi:10.1002/zaac.19261540129

27. Czochralski J. Ein neues Verfahren zur Messung des Kristallisationsgeschwindigkeit der Metalle // Zeitschrift für Physikalische Chemie. 1918. Vol. 92. P. 219.
28. Sworn C. H., Brown T. E. The growth of dislocation-free copper crystals // Journal of Crystal Growth. 1972. Vol. 15, No. 3. P. 195-203. doi:10.1016/0022-0248(72)90119-4

29. Howe S., Elbaum C. The occurrence of dislocations in crystals grown from themelt // Philosophical Magazine. 1961. Vol. 6, No. 70. P. 1227-1240. doi:10.1080/14786436108243373

30. Hukin D. A. The Levitational Zone Refining (LZR) of photovoltaic silicon // Journal of Crystal Growth. 1990. Vol. 104, No. 1. P. 93-97. doi:10.1016/0022-0248(90)90314-b

31. Carlson O. N., Schmidt F. A., Peterson D. T. Electrotransport of interstitial atoms in yttrium // Journal of the Less Common Metals. 1966. Vol. 10, No. 1. P. 1-11. doi:10.1016/0022 5088(66)90038-5

32. Schmidt F. A., Warner J. C. Electrotransport of carbon, nitrogen and oxygen in vanadium // Journal of the Less Common Metals. 1967. Vol. 13, No. 5. P. 493-500. doi:10.1016/00225088(67)90084-7

33. Peterson D. T., Schmidt F. A. Electrotransport of carbon, nitrogen and oxygen in lutetium // Journal of the Less Common Metals. 1969. Vol. 18, No. 2. P. 111-116. doi:10.1016/00225088(69)90129-5

34. Peterson D. T., Schmidt F. A. Preparation of high purity thorium and thorium single crystals // Journal of the Less Common Metals. 1971. Vol. 24, No. 2. P. 223-228. doi:10.1016/00225088(71)90099-3

35. Bradley A. J. CX. The allotropy of manganese // The London, Edinburgh, and Dublin Philosophical Magazine and Journal of Science. 1925. Vol. 50, No. 299. P. 1018-1030. doi:10.1080/ 14786442508628546

36. Mills D., Craig G. Etching dislocations in zirconium // Journal of Electrochemical Technology. 1966. Vol. 4. P. 300

37. Field W. G., Wagner R. W. Thermal imaging for single crystal growth and its application to ruby // Journal of Crystal Growth. 1968. Vol. 3-4. P. 799-803. doi:10.1016/0022-0248(68)90270-4

38. Drabble J. R. The arc transfer process of crystal growth // Journal of Crystal Growth. 1968. Vol. 3-4. P. 804-807. doi:10.1016/ 0022-0248(68)90271-6

39. Gasson D. B., Cockayne B. Oxide crystal growth using gas lasers // Journal of Materials Science. 1970. Vol. 5, No. 2. P. 100-104. doi:10.1007/bf00554627

40. Precht W., Hollox G. E. A floating zone technique for the growth of carbide single crystals // Journal of Crystal Growth. 1968. Vol. 3-4. P. 818-823. doi:10.1016/0022-0248(68)90274-1

41. Esenski B., Khartman E. Nekotorye zamechaniya o roste i mekhanicheskikh svoystvakh nitevidnykh kristallov $\mathrm{NaCl} / /$ Kristallografiya. 1962. Vol. 7. P. 433-436.

42. Berezhkova G. V., Rozhanskiy V. N. K voprosu o mekhanizmakh rosta ionnykh nitevidnykh kristallov iz rastvorov // Kristallografiya. 1963. Vol. 8. P. 420-426.

43. Glester H. Materials with ultra-fine grain size // Deformation of Polycrystals: Mechanisms and Microstructures. Roskilde: Ris. Nat. Laboratory, 1981. P. 21.

44. Glester H., Marquardt P. Nanocrystalline structures - on approach to new materials // Zeitschrift fur Metallkunde. 1984 Vol. 75, No. 4. P. 263-267.

45. Biirringer R., Herr U., Gleiler H. Nanocrystalline materials: a first report // Trans. Japan/Inst. Met. Suppl. 1986. Vol. 27. P. $43-52$

46. Gleiter H. Nanocrystalline materials // Progress in Materials Science. 1989. Vol. 33, No. 4. P. 223-315. doi:10.1016/00796425(89)90001-7

47. Siegel R. W., Hahn H. Nanjphase materials // Current Trends in Physics of materials. Singapore: World Sci. Publ. Co, 1987. P. 403-420.

48. Siegel R. W. What do we really know about the atomic-scale structures of nanophase materials? // Journal of Physics and Chemistry of Solids. 1994. Vol. 55, No. 10. P. 1097-1106. doi:10.1016/0022-3697(94)90127-9 
49. Matthews M. D., Pechenik A. Rapid Hot-Pressing of Ultrafine PSZ Powders // Journal of the American Ceramic Society. 1991. Vol. 74, No. 7. P. 1547-1553. doi:10.1111/j.1151-2916.1991. tb07138.x

50. Chen D.-J., Mayo M. J. Densification and grain growth of ultrafian $3 \mathrm{~mol} \% \mathrm{Y}_{2} \mathrm{O}_{3}-\mathrm{ZrO}_{2}$ ceramics // Nanostructured Materials. 1993. Vol. 2, No. 5. P. 469-478. doi:10.1016/09659773(93)90164-7

\section{ИССЛЕДОВАНИЕ МЕТОДОВ ПОЛУЧЕНИЯ НИТЕВИДНЫХ \\ КРИСТАЛЛОВ В КОМПОЗИЦИОННОМ МАТЕРИАЛЕ}

Исследованы методы получения нитевидных кристаллов в композиционном материале. Сосредоточено внимание на процессе получения нитевидных кристаллов путем химического взаимодействия между газом и контактным веществом, а также методом (пар - жидкость - твердое). Показано преимущество проведения процесса конденсации через жидкую фазу по сравнению с проведением процесса прямой конденсации из паровой фазы в твердую. ключевые слова: методы получения нитевидных кристаллов, композиционные материалы, химическое взаимодействие между газом и контактным веществом.

Artemev Sergey, PhD, Associate Professor, Head of the Department of Occupational Safety and Technogenic and Ecological Security, National University of Civil Defense of Ukraine, Kharkiv, Ukraine, e-mail: arctic2667@gmail.com,ORCID: http://orcid.org/0000-00029086-2856

Shaporev Valery, Doctor of Technical Sciences, Professor, Head of the Department of Chemical Technique and Industrial Ecology, National Technical University «Kharkiv Polytechnic Institute», Ukraine, ORCID: http://orcid.org/0000-0003-1652-4688

Tsymbal Bohdan, PhD, Senior Lecturer, Department of Occupational Safety and Technogenic and Ecological Security, National University of Civil Defense of Ukraine, Kharkiv, Ukraine, e-mail: tsembalbogdan@ukr.net, ORCID: https://orcid.org/00000002-2317-3428 